\title{
GLOSA DO WYROKU NACZELNEGO SĄDU ADMINISTRACYJNEGO Z DNIA 1 LIPCA 2014 ROKU, SYGN. AKT II OSK 68/13
}

\section{COMMENTARY ON THE JUDGMENT OF THE SUPREME ADMINISTRATIVE COURT OF 1 JULY 2014, II OSK 68/13}

http://dx.doi.org/10.12775/PPOS.2016.026

\section{Słowa kluczowe}

Zasada dwuinstancyjności postępowań; sądy administracyjne; pozwolenie zintegrowane; składowisko odpadów.

\section{Keywords}

The rule of two instances in proceedings; administrative courts; IPPC permit; landfill.

Doktorantka w Instytucie Nauk Prawnych Polskiej Akademii Nauk, rad- 


\section{TEZA}

Wykładnia podstaw skargi kasacyjnej, określonych w art. 174 u.p.p.s.a., prowadzi do istotnego ograniczenia prawa do sądu (art. 45 ust. 1 Konstytucji w zw. z art. 77 ust. 2 Konstytucji), rozumianego jako prawo do sprawiedliwego rozpatrzenia sprawy przez sąd, który uwzględnia zasady demokratycznego państwa prawnego (art. 2 Konstytucji), zasadę równości (art. 32 ust. 1 Konstytucji).

Glosowanie orzeczenie zapadło w związku z rozpoznawaniem skargi kasacyjnej A. Spółki z.o.o. (dalej: Spółka) od wyroku WSA w Warszawie z dnia 4 października 2012 roku sygn. akt IV SA/Wa 1226/12, którym to wyrokiem oddalono skargę tej Spółki na decyzję Ministra Środowiska w przedmiocie pozwolenia zintegrowanego dla instalacji składowiska odpadów. Z kolei wyrok Sądu pierwszej instancji (WSA w Warszawie), po rozpoznaniu skargi Stowarzyszenia, uchylił decyzję Ministra Środowiska. W uzasadnieniu Sąd pierwszej instancji wskazał, że Marszałek Województwa Mazowieckiego udzielił Spółce pozwolenia zintegrowanego na prowadzenie instalacji - składowiska odpadów innych niż niebezpieczne i obojętne. Decyzja ta została utrzymana w mocy przez Ministra Środowiska. W uzasadnieniu decyzji Minister wskazał, że organ pierwszej instancji w wydanej decyzji wyraził zgodę na zamknięcie części przedmiotowego składowiska o powierzchni 3 ha, na wysokości 170 m n.p.m., określając jednocześnie warunki tego zamknięcia, w tym termin zaprzestania składowania odpadów na tej części obiektu. Organ odwoławczy stwierdził, iż wyrażenie przez organ ochrony środowiska zgody na zamknięcie obiektu nie wymaga ani sporządzenia przez zarządzającego składowiskiem odpadów raportu o oddziaływaniu przedsięwzięcia na środowisko, ani udziału społeczeństwa w tym postępowania. Podał również, że Marsza-

4/2016 łek Województwa Mazowieckiego dokonał ustaleń powierzchni 
instalacji, biorąc pod uwagę powierzchnię działek ewidencyjnych (łączna powierzchnia 14,21 ha) i określając powierzchnię zajętą pod składowisko jako 8,7 ha. Udzielając pozwolenia zintegrowanego, organ pierwszej instancji określił parametry techniczne obiektu, w tym pozostałą do wypełnienia pojemność eksploatacyjną oraz termin obowiązywania pozwolenia. Prawidłowo określono bilans masowy surowców, materiałów i energii. Zarówno w zakresie wytwarzania, jak też odzysku i unieszkodliwiania wymieniono rodzaje odpadów, ich kody i ilości odpadów, które dopuszczono do wytwarzania w wyniku funkcjonowania instalacji i z procesów pomocniczych oraz wykorzystywanych do wykonania warstw izolacyjnych, budowy okrywy rekultywacyjnej, skarp, obwałowań, kształtowania korony składowiska, a także dopuszczonych do unieszkodliwiania na tym obiekcie. Ponadto techniczny opis dokonany pod tabelami odnoszącymi się do poszczególnych rodzajów odpadów dopuszczonych do poszczególnych metod odzysku i unieszkodliwiania nie budzi zastrzeżeń. Minister Środowiska podkreślił, że żaden z przepisów Dyrektywy Rady 96/61/WE z 24 września 1996 roku, dotyczącej zintegrowanego zapobiegania zanieczyszczeniom i ich kontroli ${ }^{1}$, nie został naruszony.

Stowarzyszenie wniosło skargę na powyższą decyzję do WSA w Warszawie. Wyrokiem z dnia 12 października 2010 roku sygn. akt IV SA/WA 2036/09 WSA w Warszawie oddalił skargę.

Następnie wyrokiem z dnia 25 kwietnia 2012 roku sygn. akt II OSK 233/11 NSA uchylił wyrok Sądu pierwszej instancji i przekazał sprawę do ponownego rozpoznania. Sąd ten stwierdził, że prowadzenie eksploatacji instalacji z zachowaniem warunków określonych w pozwoleniu zintegrowanym zasadniczo nie powoduje przekraczania standardów emisyjnych z instalacji, nie narusza też standardów jakości środowiska ani nie

1 Dyrektywa ta została transponowana do prawodawstwa krajowego w ustawie z dnia 27 kwietnia 2001 roku Prawo ochrony środowiska oraz w części dotyczącej składowiska odpadów jako instalacji wymagającej pozwolenia zintegrowanego w ustawie z dnia 27 kwietnia 2001 roku o odpadach (obecnie - ustawa z dnia 14 grudnia 2012 roku o odpadach, tekst jedn. Dz. U. z 2016 roku, poz. 1987 bez zm.) i w aktach wykonawczych. 
narusza wymagań ochrony środowiska. W celu ułatwienia wyboru, jaka konkretnie technika powinna być uznana za najlepszą dostępną technikę, w art. 207 ust. 1 i 1a ustawy z dnia 27 kwietnia 2001 roku Prawo ochrony środowiska ${ }^{2}$ ustawodawca wskazał, jakimi przesłankami powinien kierować się organ administracji wydający pozwolenie zintegrowane. W związku z tym w uzasadnieniu każdego orzeczenia w indywidualnej sprawie musi być przedstawiony przebieg wyboru konkretnej techniki.

Ponownie rozpoznając sprawę, WSA wyjaśnił, że organ odwoławczy w zaskarżonej decyzji nie zawarł rozważań dotyczących warunków izolacji składowiska. W uzasadnieniu decyzji brak jest odniesienia się zarówno do sposobu zabezpieczenia wód gruntowych przed zanieczyszczeniem, a także do zorganizowania systemu odbierania odcieków z powierzchni składowiska w sposób gwarantujący ochronę wód powierzchniowych. Jednocześnie Sąd pierwszej instancji podkreślił, że nie jest uprawniony do oceny, czy naruszanie przepisów postępowania miało wpływ na wynik sprawy w kontekście możliwości udzielenia pozwolenia zintegrowanego. Wymagałoby to bowiem przesądzenia na etapie sądowej kontroli legalności decyzji zasadności wniosku o wydanie pozwolenia, co do jego istoty, a więc m.in. przesądzenie, czy są spełnione wymagania najlepszych dostępnych technik w związku z art. 204 i 186 pkt 1 u.p.o.ś. Pełna ocena materiału dowodowego należy do organu administracji. Brak uzasadnienia w zakresie wyboru najlepszej dostępnej techniki skutkuje koniecznością uchylenia zaskarżonej decyzji. Sąd pierwszej instancji stwierdził, że w tej sytuacji przedwczesna byłaby ocena naruszenia norm prawa materialnego - warunków wydania pozwolenia. WSA nie rozstrzygał więc, czy istniejące składowisko, wobec niezastosowania wymaganych środków ochronnych, jest źródłem zanieczyszczeń wód podziemnych lub powierzchniowych (brak izolacji).

Skargę kasacyjną od powyższego wyroku wniosła spółka. Spółka podniosła następujące zarzuty: 1) naruszenie art. 207

2 Tekst jedn. z 2016 roku, poz. 672 ze zm.; dalej cyt.: u.p.o.ś. 
i art. 208 u.p.o.ś. przez błędne przyjęcie, że kwestia najlepszych dostępnych technik nie została przez organ odwoławczy należycie rozstrzygnięta i uzasadniona oraz przez przyjęcie, że zastosowanie najlepszych możliwych technik nie podlega regułom zasady swobodnej oceny dowodów materiału dowodowego; 2) naruszenie art. 191 i art. 193 ust. 4 u.p.o.ś. przez błędne przyjęcie, że istniały przesłanki procedowania w zakresie pozwolenia zintegrowanego, w sytuacji gdy w chwili orzekania pozwolenie zintegrowane nie funkcjonowało już w obrocie prawnym. W ocenie spółki Sąd pierwszej instancji błędnie przyjął, że istniały przesłanki do dalszego procedowania z uwagi na ewentualne roszczenia odszkodowawcze; 3) naruszenie art. 32-328 u.p.o.ś. przez ich niezastosowanie, pomimo że w wyroku Sąd pierwszej instancji wskazał, że może dojść do dalszego procedowania $\mathrm{z}$ uwagi na ewentualne roszczenia odszkodowawcze; 4) naruszenie art. 86 Konstytucji RP przez przyjęcie, że spółka będzie mogła ponosić odpowiedzialność za działanie bez wymaganego pozwolenia, podczas gdy przepis ten wiąże odpowiedzialność nie z brakiem pozwolenia, lecz z pogorszeniem stanu środowiska. Spółka wniosła o uchylenie zaskarżonego wyroku i przekazanie sprawy do ponownego rozpoznania WSA w Warszawie, ewentualnie uchylenie zaskarżonego wyroku i oddalenie skargi stowarzyszenia.

NSA oddalił skargę kasacyjną wniesioną przez Spółkę. W uzasadnieniu Sąd po pierwsze wskazał, iż związanie sądu drugiej instancji podstawami skargi kasacyjnej wiąże się z koniecznością prawidłowego ich sformułowania w samej skardze kasacyjnej. NSA nie może domniemywać intencji strony i samodzielnie uzupełniać czy też konkretyzować zarzutów kasacyjnych. W skardze kasacyjnej nie podano, których konkretnie jednostek redakcyjnych dotyczy zarzut naruszenia art. 207, 208, 32-328 u.p.o.ś. Po drugie, przy pomocy zarzutu naruszenia przepisów prawa materialnego nie może zwalczać ustaleń i ocen stanu faktycznego dokonanych przez organy i kontrolowanych przez Sąd pierwszej instancji. Nie ma możliwości skutecznego powoływania się na zarzut wadliwego zastosowania prawa materialnego w sytuacji, gdy nie zakwestionowano rów- 
nocześnie ustaleń stanu faktycznego, na których oparto zaskarżone rozstrzygnięcie ${ }^{3}$.

\section{II.}

Przyjęty w Polsce model skargi kasacyjnej do NSA na podstawie ustawy z dnia 30 sierpnia 2002 roku Prawo o postępowaniu przed sądami administracyjnymi ${ }^{4}$ od początku swego istnienia budził wiele kontrowersji ${ }^{5}$. Ich powstanie jest niewątpliwie wynikiem przetransponowania treści art. $174^{6}$ u.p.p.s.a. wprost z ustawy regulującej postępowanie przed sądem cywilnym. Oddalenie przez NSA skargi kasacyjnej potwierdza problem jurydyczny dotyczący art. 174 u.p.p.s.a., w tym przede wszystkim pkt $2^{7}$ tego artykułu. Określone w art. 174 u.p.p.s.a. podstawy kasacyjne nie zapewniają pełnej sądowej kontroli instancyjnej ostatecznych decyzji organów administracji publicznej, tworzą one jedynie pozory dwuinstancyjności postępowania.

W związku z tym, poza przedmiotem rozważań pozostaje sprawa, w której zapadło niniejsze orzeczenie, mianowicie

3 Por. wyroki NSA z dnia 22 października 2004 roku, GSK 811/04, CBOSA; z dnia 1 grudnia 2010 roku, II FSK 1506/09, CBOSA.

4 Tekst jedn. Dz. U. z 2016 roku, poz. 718 ze zm.; dalej cyt.: u.p.p.s.a.

5 Szczegółowe omówienie tego zagadnienia, przedstawił J.P. Tarno, Ewolucja orzecznictwa Naczelnego Sądu Administracyjnego $w$ zakresie podstaw skargi kasacyjnej i zażalenia, „Zeszyty Naukowe Sądownictwa Administracyjnego” 2010, Nr 5-6, s. 426-443.

6 Przepis ten jest wyraźnym odwzorowaniem art. 393 k.p.c. w brzmieniu obowiązującym do 5 lutego 2005 roku. Przepis ten stanowił, że kasację można oprzeć na następujących podstawach: 1) naruszeniu prawa materialnego przez błędną jego wykładnię lub niewłaściwe zastosowanie; 2) naruszeniu przepisów postępowania, jeżeli uchybienie to mogło mieć decydujący wpływ na wynik sprawy. Niniejszy przepis został uchylony ustawą z dnia 22 grudnia 2004 roku o zmianie ustawy- - Kodeks postępowania cywilnego oraz ustawy Prawo o ustroju sądów powszechnych, Dz. U. z 2005 roku Nr 13, poz. 98.

7 Zgodnie z tym przepisem skargę kasacyjną można oprzeć na zarzucie naruszenia przepisów postępowania, jeżeli uchybienie to mogło mieć istotny wpływ na wynik sprawy. 
merytoryczne aspekty pozwolenia zintegrowanego dla instalacji składowiska odpadów.

\section{III.}

Podejmując próbę wyjaśnienia przyczyn oddalenia przez NSA skargi kasacyjnej, na wstępie wskazuję, iż Konstytucja RP, stanowiąc o zasadzie dwuinstancyjności postępowania sądowoadministracyjnego, nie przesądza o konstrukcji tej zasady, odsyła do unormowania ustawowego ${ }^{8}$. Wybór sposobu ukształtowania dwuinstancyjności pozostawiono ustawodawcy. Trybunał Konstytucyjny w wyroku z dnia 16 grudnia 2008 roku (sygn. akt P 68/07) podkreślił, że z art. 176 ust. 2 Konstytucji RP wynika dyrektywa, aby instytucje odnoszące się do „postępowania sądowego" oraz materii objętej gwarancjami prawa do sądu uregulowane zostały w akcie rangi ustawowej tak zredagowanym, by jednostka mogła przewidzieć konsekwencje swoich postępowań, a także decyzje organów państwowych.

W celu doprecyzowania konstytucyjnych założeń ustawodawca wybrał model kasacyjny. Centralną pozycje zajmuje w nim skarga kasacyjna, jako środek odwoławczy od wydanego przez sąd pierwszej instancji wyroku lub, co do zasady, postanowień kończących postępowanie w sprawie ${ }^{9}$. Pomimo iż skarga kasacyjna w postępowaniu sądowoadministracyjnym mieści się w ramach najbardziej restrykcyjnego systemu środków zaskarżania, ustawodawca nie wprowadził definicji legalnej podstaw skargi kasacyjnej w postępowaniu sądowoadministracyjnym. Brak takiej definicji również w innych procedurach sądowych ${ }^{10}$. W języku potocznym „podstawa” to: rzecz, na której coś stoi, opiera się, a także: zasadniczy element czegoś, początek, pod-

8 Art. 176 Konstytucji: Postępowanie sądowe jest co najmniej dwuinstancyjne (ust. 1). Ustrój i właściwość sądów oraz postępowanie przed sądami określają ustawy (ust. 2).

9 Zob. art. $173 \S 1$ u.p.p.s.a.

10 G. Rząsa, Podstawy skargi kasacyjnej w postępowaniu sądowoadministracyjnym, „Państwo i Prawo” 2008, Nr 8, s. 56. 
walina, punkt wyjścia czegoś ${ }^{11}$. W orzecznictwie przyjmuje się, że wskazanie podstaw kasacyjnych to wymienienie przepisów, które według wnoszącego skargę kasacyjną zostały naruszone przez wojewódzki sąd administracyjny ${ }^{12}$. Tym samym to autor skargi kasacyjnej wyznacza zakres jej rozpoznania przez sąd drugiej instancji ${ }^{13}$.

W glosowanym orzeczeniu skarżący, mając na uwadze fakt, iż to skarżący w ramach podstaw, o których mowa w art. 174 u.p.p.s.a., wyznacza zakres rozpoznania skargi kasacyjnej przez NSA, powołał się na zarzuty dotyczące naruszenia prawa materialnego, wnosząc o uchylenie zaskarżonego wyroku i przekazanie sprawy do ponownego rozpoznania sądowi pierwszej instancji, ewentualnie uchylenie zaskarżonego wyroku i oddalenie skargi stowarzyszenia. Skarżący nie powołał się na zarzuty dotyczące naruszenia przepisów postępowania. W uzasadnieniu wyroku sąd drugiej instancji wskazał, iż „nie ma możliwości skutecznego powoływania się na zarzut wadliwego zastosowania prawa materialnego w sytuacji, gdy nie zakwestionowano równocześnie ustaleń stanu faktycznego, na których oparto zaskarżone rozstrzygnięcie".

W tym miejscu wskazać należy na podstawy skargi kasacyjnej, którymi zgodnie z art. 174 u.p.p.s.a., może być: 1) naruszenie prawa materialnego przez błędną jego wykładnie lub niewłaściwe zastosowanie; 2) naruszenie przepisów postępowania, jeżeli uchybienie to mogło mieć istotny wpływ na wynik sprawy. Uregulowanie to uzupełnia art. $183 \S 2^{14}$ u.p.p.s.a.,

11 E. Sobol, Mały słownik języka polskiego, Warszawa 1995, s. 653.

12 Zob. postanowienie SN z dnia 26.03.1997 r. sygn. akt II CKN 63/97, wyrok NSA z dnia 15.11. 2006 r. sygn. akt I OSK 114/06, uchwała NSA z dnia 26.10.2009 r. sygn. akt I OPS 10/09.

13 Zob. uchwała NSA z dnia 26.10.2009 r. sygn. akt I OPS 10/09, CBOSA.

14 Art. $183 \S 2$ u.p.p.s.a.: Nieważność postępowania zachodzi: 1) jeżeli droga sądowa była niedopuszczalna; 2) jeżeli strona nie miała zdolności sądowej lub procesowej, organu powołanego do jej reprezentowania lub przedstawiciela ustawowego, albo gdy pełnomocnik strony nie był należycie umocowany; 3) jeżeli w tej samej sprawie toczy się postępowanie wcześniej wszczęte przed sądem administracyjnym albo jeżeli sprawa taka została już prawomocnie osądzona; 4) jeżeli skład sądu orzekającego był sprzeczny z przepisami prawa albo jeżeli w rozpoznaniu sprawy brał udział sędzia wyłączony z mocy 
w którym wymieniono okoliczności traktowane jako podstawa nieważności postępowania, brane pod uwagę przez NSA z urzędu. Przy sporządzaniu skargi pamiętać również należy o konieczności spełnienia przez skargę kasacyjną wymogów formalnych. Za B. Dauterem ${ }^{15}$ można podzielić je na dwie kategorie: wymagania przewidziane dla pisma w postepowaniu sądowym, a także wymagania szczególne (konstrukcyjne) przewidziane tylko dla skargi kasacyjnej. Pierwsza kategoria obejmuje w szczególności takie wymagania formalne, jak ${ }^{16}$ : oznaczenie sądu, do którego skarga kasacyjna jest skierowana, oznaczenie rodzaju pisma, sygnaturę akt, imię i nazwisko lub nazwę stron, ich przedstawicieli ustawowych i pełnomocników. Szczególne wymagania formalne skargi kasacyjnej zostały z kolei określone w art. 176 u.p.p.s.a. Są nimi: oznaczenie zaskarżonego orzeczenia; wskazanie czy jest ono zaskarżone w całości, czy w części; przytoczenie podstaw kasacyjnych i ich uzasadnienie; wniosek o uchylenie lub zmianę orzeczenia; oznaczenie zakresu żądanego uchylenia lub zmiany.

Zatem, dla zachowania formy skargi kasacyjnej nie jest wystarczające powołanie się na art. 174 u.p.p.s.a. (tj. przepis wymieniający podstawy skargi kasacyjnej), ale konieczne jest także uzasadnienie w myśl art. 176 ust. 1 pkt 2) u.p.p.s.a. podnoszonej podstawy kasacyjnej, przez wskazanie które przepisy ustawy zostały naruszone. Podkreślić należy, iż przepisy dotyczące skargi kasacyjnej w art. 174 u.p.p.s.a. ograniczają się jedynie do wskazania jej podstaw. Z literalnej wykładni tego artykułu wynika, iż każda z tych podstaw jest samodzielną i niezależną podstawą kasacyjną, a contrario: artykuł ten nie podaje, kiedy i na którą podstawę kasacyjną skarżący może się powołać. Artykuł ten nie zawiera spójników: „albo”, „i”, „lub”, które wskazywałyby na możliwość powoływania w skardze kasacyj-

ustawy; 5) jeżeli strona została pozbawiona możności obrony swych praw; 6) jeżeli wojewódzki sąd administracyjny orzekł w sprawie, w której jest właściwy Naczelny Sąd Administracyjny.

15 B. Dauter, Zarys metodyki pracy sędziego sq̨du administracyjnego, Warszawa 2008, s. 346.

16 Zob. art. 46, art. 47, art. $215 \S 1$ u.p.p.s.a. 
nej podstaw kasacyjnych, tj. kiedy skarżący w skardze kasacyjnej może powołać się tylko na jedną podstawę, obie podstawy łącznie czy też wybór pomiędzy podstawami (na które można się powołać), pozostawiono skarżącemu. W tej sytuacji wymaga rozważenia, $\mathrm{w}$ jaki sposób należy zakwalifikować milczenie prawodawcy ${ }^{17}$ dotyczące zarzutów kasacyjnych, których prawidłowe przytoczenie ma kluczowe znaczenie dla prowadzenia postępowania kasacyjnego. Ocena skutków takiego milczenia musi zostać dokonana w odniesieniu do każdej konkretnej normatywnej sytuacji.

Po pierwsze, wskazać należy, iż ustawodawca projektując art. 174 u.p.p.s.a., zapomniał o dystynkcji między rolą i charakterem orzeczeń sądu cywilnego i administracyjnego. W postępowaniu przed sądami cywilnymi skarga kasacyjna jest środkiem odwoławczym kierowanym w toku instancji do Sądu Najwyższego w celu ostatecznej kontroli zgodności z prawem orzeczeń sądów drugiej instancji. W postępowaniu przed sądami administracyjnymi jest to natomiast środek zaskarżenia orzeczeń pierwszoinstancyjnych. Inna jest także (w porównaniu z sądami w postępowaniu cywilnym), rola sądów administracyjnych, które jedynie kontrolują działalność administra-

17 Problem milczenia ustawodawcy nie jest przedmiotem znacznego zainteresowania zarówno teorii prawa, jak i nauk dogmatycznych. W jednym z ostatnich opracowań, poniekąd systematyzujących dotychczasowy dorobek jurysprudencji, Z. Tobor wskazał, że „milczenie ustawodawcy jest traktowane zarówno w literaturze, jak i w orzecznictwie jako przejaw jego intencji. Milczenie prawodawcy może być równie znaczące, co jego wypowiedzi. [...] Poczyniono kilka rozróżnień, na które warto zwrócić uwagę. Po pierwsze, odróżnia się milczenie prawodawcy w tekście od braku śladów intencji w materiałach legislacyjnych. Jeden $\mathrm{z}$ autorów przypisuje milczeniu prawodawcy dwa w gruncie rzeczy podobne znaczenia: jako wyraz zgody na interpretację dokonywaną przez sądy oraz w przypadkach powtarzania w nowych tekstach przepisów w starym brzmieniu - jako przejaw inkorporacji sądowej interpretacji. Inny autor koncepcję milczenia prawodawcy opiera na trzech regułach: regule przyzwolenia (brak zmiany jako przyzwolenia na sposób interpretacji przepisów), regule powtórzenia (reenactment rule - powtórzenie przepisów jest równoznaczne $\mathrm{z}$ aprobatą dotychczasowej interpretacji) oraz na regule odrzuconych poprawek (wskazanie nieakceptowanych sposobów interpretacji)". Z. Tobor, W poszukiwaniu intencji prawodawcy, Warszawa 2013, s. 255-256. 
cji publicznej ${ }^{18}$, a kontrole tę sprawują przede wszystkim pod względem zgodności z prawem. Jak podniosła B. Adamiak, sądy administracyjne orzekają kasacyjnie w sprawach, które wcześniej były przedmiotem postępowania administracyjnego (przedmiotem dwukrotnego merytorycznego rozpoznania i rozstrzygnięcia). ${ }^{19}$ Także R. Hausner przyznaje, że zadaniem sądu administracyjnego jest dokonanie oceny (kontroli) działalności administracji publicznej. Sąd administrayjny - co do zasady „nie może zastępować organu administracji i wydawać końcowego rozstrzygnięcia w sprawie". Trafnie wywodzi, że przyjęcie przez sąd administracyjny kompetencji organu administracji byłoby wykroczeniem „poza konstytucyjne określone granice kontroli administracji publicznej". Tym samym prowadziłoby to „wprost do zmiany funkcji sądu, który stawałby się administratorem"20. Sądy administracyjne nie stosują prawa materialnego w taki sposób, jak czyni to Sąd Najwyższy oraz sądy powszechne i wojskowe. Poza rzadkimi sytuacjami, w których pojawiają się elementy orzekania merytorycznego (np. w sprawach skarg na bezczynność organu administracji czy rozstrzygania sporów o właściwość), sądy administracyjne nie stosują prawa materialnego, w związku z tym nie mogą stosować go „niewłaściwie”. One rekonstruują jedynie normę ustanawiającą na rzecz organu administracji szeroko rozumianą kompetencję do określonego zachowania - normę dopełnienia (etap wykładni), a następnie badają, czy prawidłowo „podciągnięto” pod hipotezę tej normy rozpatrywany stan faktyczny (etap subsumpcji) ${ }^{21}$.

Po drugie, nie każde uchybienie $\mathrm{w}$ postaci naruszenia przepisów postępowania może stanowić podstawę kasacyjną, ale tylko takie które mogło mieć istotny wpływ na wynik spra-

18 Zob. art. 184 Konstytucji RP.

19 B. Adamiak, Uwagi o modelu dwuinstancyjnego postępowania sądowoadministracyjnego, w: Procedura administracyjna wobec wyzwań wspótczesności. Profesorowi zwyczajnemu dr hab. Januszowi Borkowskiemu przyjaciele i uczniowie, Łódź 2004, s. 29.

20 R. Hausner, Założenia reformy sądownictwa administracyjnego, „Państwo i Prawo" 1999, Nr 12, s. 22-24.

21 Z. Kmiecik, Podstawy skargi kasacyjnej do Naczelnego Sądu Administracyjnego, „Państwo i Prawo” 2005, Nr 1, s. 19-20. 
wy. Zgodnie z art. 174 pkt 2 u.p.p.s.a. skargę kasacyjną można oprzeć na „naruszeniu przepisów postępowania, jeżeli uchybienie to mogło mieć istotny wpływ na wynik sprawy. „Istotny” to: „stanowiący istotę czegoś, charakterystyczny, ważny, główny, zasadniczy, podstawowy”22. „Wpływ” to: „oddziaływanie, sugestia”, a także jako fraza: „wywierać wpływ”23. Tym samym posłużenie się przez ustawodawcę słowem „wpływ” świadczy, że między wytkniętym uchybieniem procesowym a wynikiem sprawy, który przybiera postać wyroku (orzeczenia) sądowego, musi zachodzić związek przyczynowy ${ }^{24}$. Wpływ naruszenia prawa procesowego na wynik sprawy musi być „istotny”, nie wystarczy zatem wskazanie w skardze kasacyjnej naruszenia przepisów postępowania. Skarżący musi również wykazać, że skutki wadliwości postępowania wpłynęły na treść zaskarżonego orzeczenia.

Mając na uwadze treść powołanych przez skarżącego zarzutów oraz przebieg dotychczasowych postępowań administracyjnych, jak i sądowoadministracyjnych, stwierdzić można, iż w ocenie skarżącego brak było naruszenia przepisów postępowania, które mogło mieć istotny wpływ na wynik sprawy. Natomiast analizując uzasadnieniu wyroku, nie ulega wątpliwości, iż w ocenie NSA skarżący, poza wskazaniem zarzutów naruszenia prawa materialnego, zobowiązany był podnieść także zarzut naruszenia prawa procesowego, bowiem „przy pomocy zarzutu naruszenia prawa materialnego, nie można zwalczać ustaleń i ocen stanu faktycznego dokonanych przez organy i kontrolowanych przez sad pierwszej instancji”. W ocenie skarżącego stan faktyczny, na którym oparto zaskarżone rozstrzygnięcie, został ustalony i oceniony przez organy administracji $\mathrm{w}$ sposób prawidłowy, w związku z tym możliwa była ocena przez sąd drugiej instancji zastosowania właściwych przepisów prawa materialnego. Tym samym, poprzez nie odniesienie się do postawionych przez skarżącego zarzutów, NSA potwierdził, iż

22 E. Sobol, op. cit., s. 272.

23 E. Sobol, op. cit., s. 1037.

24 Zob. H. Knysiak-Molczyk, w: Prawo o postępowaniu przed sądami administracyjnymi. Komentarz, T. Woś (red.), Warszawa 2005, s. 545. 
zasada dwuinstancyjności postępowania sądowego, wynikająca z art. 176 ust. 1 Konstytucji RP, nie oznacza prawa strony do dwukrotnego rozpatrzenia jej sprawy przez sąd administracyjny.

Poza odniesieniem się do podstaw skargi kasacyjnej, w tym w szczególności podstawy z art. 174 pkt 2 u.p.p.s.a., chciałabym również wskazać na sposób prawidłowego formułowania jej podstaw. W uzasadnieniu skargi NSA podał, iż skarżący nie wskazał których jednostek redakcyjnych dotyczy zarzut naruszenia art. 207, 208 oraz 322-328 u.p.o.ś.

W ślad za J.P. Tarno wyjaśniam, że początkowo NSA był niezwykle restrykcyjny w zakresie wymagań konstrukcyjnych skargi kasacyjnej. Kwestia formułowania podstaw kasacyjnych była rozumiana w sposób ścisły. Każde uchybienie w tym względzie powodowało odrzucenie skargi kasacyjnej albo jej oddalenie z uzasadnieniem, że została ona określona nieprecyzyjnie. Jednocześnie w orzecznictwie NSA daje się dostrzec drugi, liberalny nurt pojmowania wymogów prawidłowej konstrukcji podstaw kasacyjnych. Dominuje w nim ocena prawna, że przytoczenie podstaw kasacyjnych powinno być na tyle wyraźne, aby umożliwić sądowi drugiej instancji ustalenie granic zaskarżenia. Obecnie uprawnione jest więc twierdzenie, że wskazanie naruszonego przepisu (normy) dopiero w uzasadnieniu skargi kasacyjnej, nie mogą jej dyskwalifikować (nieścisłość ta nie umożliwia ustalenia granic skargi kasacyjnej) ${ }^{25}$. Zamieszczenie zarzutu będącego podstawą kasacyjną dopiero w uzasadnieniu skargi kasacyjnej stanowi wprawdzie uchybienie zasadom wynikającym $\mathrm{z}$ art. 176 u.p.p.s.a., ale nie umożliwia rozpoznania tego zarzutu, jeżeli został on sprecyzowany w stopniu umożliwiającym sądowi administracyjnemu wyznaczenie granic skargi kasacyjnej $^{26}$. Dla zachowania ustawowych wymagań skargi kasacyjnej nie ma zasadniczego znaczenia, w którym miejscu pisma procesowego zostały zamieszczone, wymagane $\mathrm{z}$ art. 174 pkt 1 i 2 u.p.p.s.a. oraz z art. 176 u.p.p.s.a., poszczególne elementy skargi kasacyjnej ${ }^{27}$.

25 J.P. Tarno, op.cit., s. 430-433.

26 Wyrok NSA z dnia 18 lutego 2009 r., sygn. akt I OSK 409/2008.

27 Wyrok NSA z dnia 20 grudnia 2006 r., sygn. akt I FSK 312/2006. 
W związku z tym, jeżeli z uzasadnienia skargi kasacyjnej wynikało, których konkretnie jednostek redakcyjnych (tj. ustępów, punktów czy podpunktów) dotyczył zarzut kasacyjny, sąd zobowiązany był rozpoznać ten zarzut, a nie podnosić bez odniesienia się do uzasadnienia skargi kasacyjnej, iż podstawy skargi kasacyjnej zostały określone w sposób nieprawidłowy. Poprzez brak analizy uzasadnienia skargi kasacyjnej, którego sporządzenie jest jednym z wymogów formalnych skargi, sąd naruszył art. 141§4 zd. 1 u.p.p.s.a., w myśl którego: uzasadnienie wyroku poza zwięzłym przedstawieniem stanu sprawy, stanowisk pozostałych stron, podstawy prawnej rozstrzygnięcia oraz jej wyjaśnienia, powinno również zawierać przedstawienie zarzutów podniesionych w skardze. Sposób prezentacji tych zarzutów przez NSA nie jest zgodny zarówno z wymogami dotyczącymi uzasadnienia skargi kasacyjnej, jak i podanym w tym zakresie stanowiskiem doktryny i orzecznictwa.

Reasumując, odnosząc się do podstaw skargi kasacyjnej, podkreślam, iż ukształtowanie podstaw skargi kasacyjnej do NSA odpowiada konstrukcji właściwej dla postępowania cywilnego, stanowiącej bez wątpienia źródło inspiracji dla twórców projektu ustawy prawo o postępowaniu przed sądami administracyjnymi. Określając je, nie uznano za celowe dokonanie dalej idącej modyfikacji formuły wyjściowej czy nawet wprowadzenie całkowicie nowej instytucji weryfikacji orzeczeń sądów pierwszej instancji. Problem sprowadza się przecież do tego, aby zapewniając realną, przy odpowiednim stopniu sformalizowania środków odwoławczych, kontrolę instancyjną, zapobiec nadmiernej przewlekłości postępowania sądowoadministracyjnego i zalania NSA skargami ${ }^{28}$.

W obecnym kształcie podstawy skargi kasacyjnej zakreślone są zbyt wąsko, a - co więcej - w sposób niejasny. Stawia to w kłopotliwej sytuacji sporządzających skargi (czego przykładem jest niniejszy wyrok), a więc profesjonalistów wskazanych $\mathrm{w}$ art. 175 u.p.p.s.a., którzy dopiero po zapoznaniu się z uzasadnieniem wyroku oddalającego skargę przekonują się o rzeczywistym zakresie gwarantowanej przez tę ustawę ochrony.

28 Z. Kmiecik, op.cit., s. 27. 
Wynikająca z art. 176 ust. 1 Konstytucji RP zasada dwuinstancyjności postępowania sądowego nie oznacza prawa strony do dwukrotnego rozpatrzenia jej sprawy przez sąd administracyjny. W wyniku wadliwego określenia w art. 174 pkt 1 i 2 u.p.p.s.a. podstaw kasacyjnych stworzone zostały jedynie pozory dwuinstancyjności postępowania. Nie zapewniają one rzeczywistej kontroli działalności administracji publicznej w drugiej instancji sądowej. Poprzez recypowanie wprost z kodeksu postępowania cywilnego podstaw skargi kasacyjnej, wprowadzonych dla potrzeb postępowania przed sądami cywilnymi wykonującymi merytoryczną (a zatem odmienną rodzajowo) jurysdykcję, przede wszystkim to ustawodawca, a następnie dopiero sąd drugiej instancji. wydający na podstawie tych przepisów wyrok, naruszył prawo do sądu, wyrażone expressis verbis $\mathrm{w}$ art. 45 ust. 1 oraz w art. 77 ust. 2 Konstytucji RP.

Niemniej krytycznie należy ocenić wyrok zapadły w niniejszej sprawie. Nie każde bowiem uchybienie w postaci naruszenia przepisów postępowania może stanowić podstawę kasacyjną, ale tylko takie, które mogło mieć istotny wpływ na wynik sprawy. Tym samym, nie można zgodzić się ze stanowiskiem NSA, iż poprzez brak wskazania naruszenia przepisów postępowania, Sąd nie mógł odnieść się do postawionych przez skarżącego zarzutów naruszenia prawa materialnego.

Mając na uwadze konieczność realizacji celów kontroli instancyjnej w postępowaniu sądowoadministracyjnym, komentowane orzeczenie skłania również do refleksji w zakresie zasad prawidłowej legislacji. Nie ulega wątpliwości, iż zmiana przepisów o skardze kasacyjnej jest zasadna ${ }^{29}$. Otwarta pozostaje wszakże kwestia, czy ograniczyć się jedynie do techniczno-redakcyjnej korekty art. 174 u.p.p.s.a., czy też zdecydować się na bardziej ambitne posunięcie, tj. przyjąć nową formułę kasacji.

29 Stanowisko to podziela: B. Gruszczyński, Skarga kasacyjna w postępowaniu przed Naczelnym Sądem Administracyjnym, „Zeszyty Naukowe Sądownictwa Administracyjnego" 2005, Nr 1, s. 17-32; M. Wiącek, Skarga kasacyjna do Naczelnego Sądu Administracyjnego (w świetle orzecznictwa), „Państwo i Prawo" 2011, Nr 3, s. 54.; Z. Kmiecik, op.cit., s. 27-28; G. Rząsa, op.cit., s. 64-65. 


\section{BIBLIOGRAFIA}

Adamiak B., Uwagi o modelu dwuinstancyjnego postępowania sądowoadministracyjnego, w: Procedura administracyjna wobec wyzwań wspótczesności. Profesorowi zwyczajnemu dr hab. Januszowi Borkowskiemu przyjaciele i uczniowie, Łódź 2004.

Dauter B., Zarys metodyki pracy sędziego sądu administracyjnego, Warszawa 2008.

Gruszczyński B., Skarga kasacyjna $w$ postępowaniu przed Naczelnym Sadem Administracyjnym, „Zeszyty Naukowe Sądownictwa Administracyjnego" 2005, Nr 1.

Hausner R., Założenia reformy sądownictwa administracyjnego, „Państwo i Prawo" 1999, Nr 12.

Kmiecik Z., Podstawy skargi kasacyjnej do Naczelnego Sądu Administracyjnego, „Państwo i Prawo” 2005, Nr 1.

Knysiak-Molczyk H., w: Prawo o postępowaniu przed sq̨ami administracyjnymi. Komentarz, T. Woś (red.), Warszawa 2005.

Rząsa G., Podstawy skargi kasacyjnej w postępowaniu sq̨dowoadministracyjnym, „Państwo i Prawo” 2008, Nr 8.

Sobol E., Mały słownik języka polskiego, Warszawa 1995.

Tarno J.P., Ewolucja orzecznictwa Naczelnego Sadu Administracyjnego $w$ zakresie podstaw skargi kasacyjnej i zażalenia, „Zeszyty Naukowe Sądownictwa Administracyjnego" 2010 Nr 5-6.

Tobor Z., W poszukiwaniu intencji prawodawcy, Warszawa 2013.

Wiącek M., Skarga kasacyjna do Naczelnego Sądu Administracyjnego (w świetle orzecznictwa), „Państwo i Prawo” 2011, Nr 3.

Kontakt e-mail:

k.kaczmarek2@op.pl 